\title{
Penerapan pupuk hayati dalam meningkatkan produksi jagung (Zea mays L.) di Kabupaten Limapuluh Kota
}

\author{
Yun Sondang*, Ramond Siregar, dan Khazy Anty
}

Politeknik Pertanian Negeri Payakumbuh

* silitonga_yun@yahoo.co.id

\begin{abstract}
Abstrak. Tujuan dari kegiatan ini adalah mendesiminasikan hasil penelitian dalam upaya meningkatkan produksi jagung di Kabupaten Limapuluh Kota, meningkatkan pengetahuan dan keterampilan masyarakat (kelompok tani dan mahasiswa) dalam pembuatan dan penggunaan pupuk hayati, serta teknik budi daya jagung. Metode yang digunakan adalah "Alih Teknologi" dengan pendekatan secara terpadu untuk memotivasi masyarakat dalam program pertanian berkelanjutan dengan metode pelatihan, pendampingan, dan demonstrasi plot yang dilaksanakan di Rumah Kompos dan Kebun Percobaan Politeknik Pertanian Negeri Payakumbuh dari bulan Agustus 2018-Juni 2019. Pelaksanaan terdiri dari tiga tahap, yaitu Pelatihan in house, Pembuatan pupuk hayati dan Aplikasi pupuk hayati pada tanaman jagung. Sumber inokulan bakteri adalah genera Bacillus dan Pseudomonas yang merupakan hasil isolasi dan identifikasi dari tiga lokasi tanaman bambu, jagung, dan padi di Kabupaten Limapuluh Kota. Bakteri diinokulasi pada saat pembuatan pupuk hayati berbahan eceng gondok dan difermentasi selama 6 minggu, selanjutnya diaplikasikan pada lahan demplot seluas $250 \mathrm{~m} 2$. Hasil kegiatan menunjukkan antusias masyarakat dalam mengikuti pelatihan pembuatan pupuk hayati dan demplot. Luaran berupa peningkatan produksi jagung sebesar 19\% dibandingkan tanpa pupuk hayati, peningkatan pengetahuan dan keterampilan masyarakat dalam membuat serta mengaplikasikan pupuk hayati pada tanaman meningkat $20-30 \%$.
\end{abstract}

Kata kunci: bakteri; inokulasi; jagung; penerapan; pupuk hayati

\begin{abstract}
The objectives of this activity are to disseminate the results of research to increase corn production in Limapuluh Kota District, to increase knowledge and skills of the community in making and using biofertilizers, and corn cultivation techniques. The method used is "Technology Transfer" with an integrated approach to motivate the community in a sustainable agriculture program with training, mentoring, and demonstration methods in Payakumbuh State Agriculture Polytechnic Experimental Field from August 2018-June 2019. The implementation consists of three stages: Training in house, manufacture of biofertilizers and application of biofertilizers on corn plants. Sources of bacterial inoculants are the Bacillus and Pseudomonas genera which are the result of isolation and identification of three locations of bamboo, corn, and rice plants in Limapuluh Kota District. Bacteria were inoculated when biofertilizers made from water hyacinth and fermented for 6 weeks and applied to a plot of land measuring $250 \mathrm{~m} 2$. The results showed the enthusiasm of the community in participating to make biofertilizers and demonstration plots. The output of this activity: Increased corn production 19\% than without biofertilizer, increased of knowledge and skills of community in making and applying biofertilizers on plant increased $20-30 \%$.
\end{abstract}

Keywords: application; bacteria; biofertilizer; corn; inoculation

To cite this article: Sondang, Y., R. Siregar, \& K. Anty. 2019. Penerapan pupuk hayati dalam meningkatkan produksi jagung (Zea mays L.) di Kabupaten Limapuluh Kota. Unri Conference Series: Community Engagement 1: 202-209. https://doi.org/10.31258/unricsce.1.202-209 


\section{PENDAHULUAN}

Jagung (Zea mays L.) merupakan komoditas penghasil karbohidrat ketiga di dunia setelah gandum dan padi. Tanaman jagung bernilai ekonomis tinggi karena mulai dari akar, batang, daun dan biji bisa dimanfaatkan untuk kebutuhan mahluk hidup. Permintaan jagung di Kabupaten Limapuluh Kota meningkat seiring dengan perkembangan usaha ternak ayam, namun belum bisa dipenuhi dari produksi jagung petani di Kabupaten Limapuluh Kota. Permintaan biji jagung terbesar pada industri pakan ternak $(51,4 \%)$, industri makanan (minyak goreng, tepung maizena) dan industri farmasi (etanol, pentose) (Nuryati, Waryanto, Noviati dan Widaningsih, 2015). Selama periode tahun 2010-2016 rata-rata penggunaan jagung untuk industri pakan ternak Indonesia meningkat secara signifikan $15,81 \%$ per tahun (Sulaiman, Kariyasa, Hoerudin, FoodSt, Subagyono, Suwandi dan Bahar, 2017), Upaya untuk memenuhi permintaan pasar akan jagung perlu dilakukan suatu teknologi peningkatan hasil untuk mendongkrak produksi di tingkat petani menjadi lebih meningkat.

Petani di Indonesia saat ini masih menggunakan pupuk anorganik secara terus menerus dengan dosis yang berlebihan. Petani beranggapan semakin banyak pupuk yang digunakan semakin tinggi hasil yang diperoleh. Padahal pada kenyataannya peningkatan dosis pupuk anorganik tidak lagi seiring dengan peningkatan hasil. Balai Penelitian Tanah (2005) menyatakan bahwa pada tanah-tanah di Indonesia dampak dari pemupukan N secara berlebihan akan mengakibatkan pemadatan tanah, pemupukan $\mathrm{P}$ yang berlebihan mengakibatkan penumpukan $\mathrm{P}$ di dalam tanah dan tidak dapat dimanfaatkan oleh tanaman, sementara pengurasan bahan organik terus berlangsung pada saat panen. Untuk merubah paradigma ini diperlukan peranan Perguruan Tinggi dalam merubah sikap petani untuk beralih ke penggunaan pupuk hayati dan mengurangi secara perlahan penggunaan pupuk anorganik.

Upaya penyuluhan tentang pupuk organik sebenarnya sudah pernah dilakukan oleh pihak lain di Kabupaten Limapuluh Kota, namun baru sebatas penyuluhan cara pembuatan pupuk hayati, belum sampai kepada aplikasinya kepada tanaman di lapangan, sehingga masyarakat belum dapat melihat secara langsung hasil nyata dari aplikasi pupuk hayati. Kegiatan pengabdian ini dilakukan tiga tahap, (1) Desiminasi teknologi POH, (2) Pelatihan dan pembuatan pupuk hayati dan (3) Demonstrasi plot penggunaan pupuk hayati pada tanaman jagung di lapangan.

Tujuan kegiatan pengabdian adalah untuk mendesiminasikan hasil penelitian dalam upaya meningkatkan produksi jagung di Kabupaten Limapuluh Kota, meningkatkan pengetahuan dan keterampilan masyarakat (kelompok tani dan mahasiswa) dalam pembuatan dan penggunaan pupuk hayati, serta teknik budi daya jagung.

\section{MASALAH}

Permasalahan pupuk anorganik, menurunnya kualitas lahan, dan penurunan produksi tanaman pangan, terutama jagung dapat mengancam program ketahanan pangan Nasional. Fenomena yang sama dapat dilihat dari produksi jagung di Kabupaten Limapuluh Kota yang belum mampu mencukupi permintaan jagung yang cukup tinggi, sehingga jagung harus dipasok dari luar Kabupaten. Tidak optimalnya produksi jagung disebabkan karena tidak efektifnya penggunaan pupuk anorganik yang berdampak pada terganggunya mekanisme siklus hara di dalam tanah. Akibatnya unsur hara tidak tersedia bagi tanaman terutama unsur hara $\mathrm{P}$ dan K. Seiring dengan penurunan sifat kimia tanah, bahan organik yang terbawa saat panen menyebabkan kandungan bahan organik tanah menjadi rendah. Pringadi (2009) melaporkan 73\% lahan pertanian Indonesia kandungan bahan organiknya kurang dari $2 \%$, sehingga mikroorganisme tanah menjadi mati dan tanah memadat. Upaya mengatasi bahan organik yang rendah dilakukan dengan pengembalian bahan organik ke dalam tanah. Rusastra, Saptana, dan Djulin (2005) menyatakan kesuburan tanah dapat diperbaiki dengan cara pengembalian bahan organik ke dalam tanah. Martinez-Alcantara, Martinez-Cuenca, Bermejo, Legaz, and Quinones (2016) menyatakan pupuk cair yang berasal dari limbah jagung dan kotoran domba dapat menggantikan pupuk mineral buatan pabrik, meningkatkan kesuburan kimia tanah dan meningkatkan bahan organik tanah.

Persoalannya petani belum menyadari dampak negatif dari penggunaan pupuk anorganik terhadap tanah dan produk tanaman. Ditambah penggunaan pupuk anorganik secara intensif dengan dosis berlebihan ditingkat petani, tidak bisa diharapkan lagi sebagai pemenuhan nutrisi untuk meningkatkan produksi tanaman jagung. Sikap petani yang tidak mau repot dan selalu ingin melihat hasil peningkatan dalam waktu singkat menyebabkan petani susah untuk menerima inovasi baru.

Beberapa permasalahan yang dapat diidentifikasi dari uraian di atas:

1. Produksi jagung belum optimal 
2. Pupuk anorganik berdampak negatif terhadap tanah dan tanaman

3. Pupuk hayati siap pakai belum tersedia di pasaran

4. Petani masih susah untuk menerima teknologi baru

Produksi jagung dapat ditingkatkan dengan teknologi yang aman dan ramah lingkungan, salah satunya dengan penggunaan pupuk hayati. Upaya pengurangan pupuk organik dan beralih ke penggunaan pupuk hayati yang diformulasi dari eceng gondok yang diinokulasi dengan konsorsium bakteri merupakan solusi dari pemasalahan pupuk. Mikroba indigenus terdiri dari bakteri yang dapat mengikat nitrogen dan melarutkan fosfor, serta menyumbang hara makro (Sondang, Alfina dan Anty, 2015), dan mendekomposisi bahan organik (Sondang dan Anty, 2017). Malusa and Vassilev (2014) mendefinisikan pupuk hayati adalah produk pupuk yang diformulasikan dan mengandung beberapa mikroba untuk meningkatkan status hara tanaman.

Ketersediaan hara N, P, K bagi tanaman dapat ditingkatkan dengan bantuan bakteri menguntungkan. Bakteri pengikat $\mathrm{N}$, pelarut $\mathrm{P}$ dan $\mathrm{K}$ dapat diperoleh dari pupuk hayati. Pemupukan berbasis hayati merupakan pemupukan yang aman bagi tanah, tidak menimbulkan efek residu pada hasil dan ramah terhadap lingkungan. Teknologi pupuk hayati harus diperkenalkan kepada masyarakat tani untuk merubah ketergantungan terhadap pupuk anorganik. Masyarakat harus diberi pelatihan dan pendampingan dalam pembuatan pupuk hayati dan aplikasinya pada tanaman, sehingga dampaknya dapat dilihat langsung oleh masyarakat.

Tantangannya untuk mendapat teknologi ini membutuhkan waktu yang lama dalam proses pembuatannya. Keberhasilannya terhadap peningkatan produksi membutuhkan sekurang-kurangnya 2 tahun baru hasilnya dapat dilihat, karena membutuhkan jumlah bahan organik yang banyak dengan penggunaan secara terusmenerus. Petani butuh pendampingan yang intensif agar tetap konsisten dalam menerapkan pupuk hayati.

Jagung dalam pakan ternak sebesar 51,4\% menyebabkan para peternak sangat tergantung akan jagung, sehingga peternak tetap berusaha menanam jagung walaupun produksinya tidak optimal. Target pelaksana kegiatan adalah meningkatkan produksi jagung dan merubah sikap petani agar menggunakan pupuk organik.

\section{METODE PENERAPAN}

Pelaksanaan pengabdian kepada masyarakat dilaksanakan 2 tahap, pertama di Rumah Kompos pada bulan Agustus 2018 dan kedua di Kebun Percobaan Politeknik Pertanian Negeri Payakumbuh dari bulan SeptemberJuni 2019 dengan dua kali musim tanam. Kelompok Tani yang dilibatkan K.T. Usaha Subur Batu Balang, K.T. Setia Kawan Sarilamak, K.T. Agriprima Payakumbuh, Alumni dan mahasiswa calon wirausaha baru.

Metode yang digunakan untuk penyelesaian masalah di atas adalah "Alih Teknologi" dengan pendekatan secara terpadu untuk memotivasi masyarakat dalam program pertanian berkelanjutan dengan metode pelatihan, pendampingan dan demonstrasi plot.

\section{Desiminasi Teknologi POH Hasil Penelitian}

Preparasi Konsorsium Mikroba. Konsorsium mikroba berasal dari mikroba yang diisolasi dari rizosfer dan akar tanaman bambu, jagung dan padi sawah. Mikroba diisolasi dari endofit dan rizosfer dengan teknik pengenceran $10^{-6}$ (Schaad, Jones and Chun, 2001). Setelah diperoleh biakan murni bakteri, diidentifikasi untuk memperoleh jenis dan spesies bakteri yang menguntungkan. Bakteri disimpan sebagai bahan inokulasi pada pembuatan $\mathrm{POH}$.
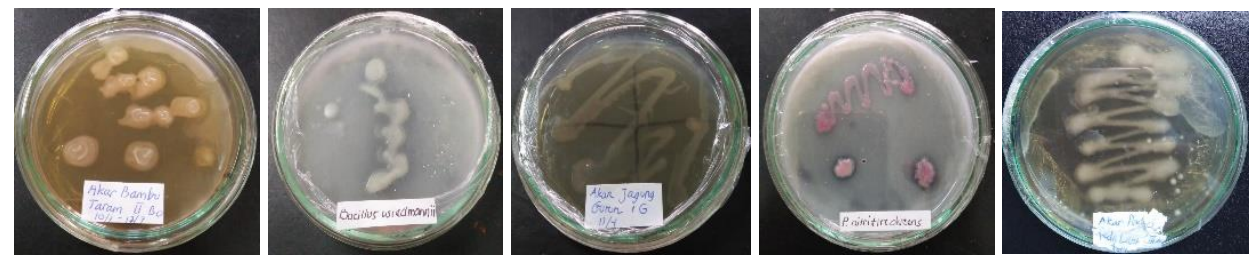

Gambar 1. Konsorsium bakteri yang akan diinokulasi ke dalam $\mathrm{POH}$

Pembuatan Suspensi Bakteri. Suspensi bakteri dibuat dengan menginokulasi 1 jarum ose bakteri hasil identifikasi dan ditumbuhkan pada media NA sampai kepadatan $10^{7} \mathrm{sel} / \mathrm{ml}$. Suspensi bakteri yang telah mencapai kepadatan $10^{7}$ ditambahkan aquades berisi $100 \mathrm{ml}$ untuk mendapatkan suspensi sebanyak $100 \mathrm{ml}$. Suspensi yang dibuat digunakan untuk dinokulasi pada POH dan benih jagung. 


\section{Pelatihan dan Pembuatan POH kepada Masyarakat}

Tahap I, Pelatihan in house berupa teori dan diskusi tentang pupuk hayati.
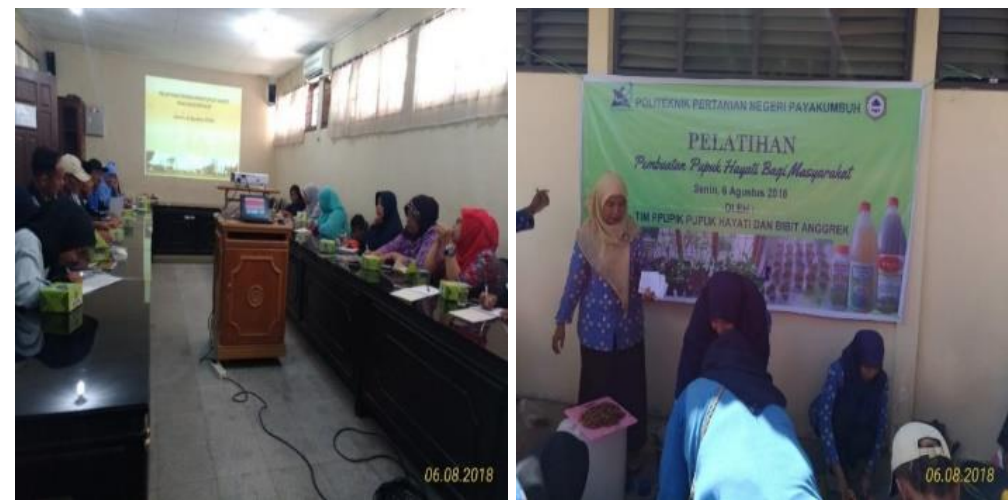

Gambar 2. Pelatihan in house dan diskusi

Tahap 2, Demonstrasi pembuatan pupuk hayati. POH dibuat dengan komposisi $10 \mathrm{~kg}$ eceng gondok, $10 \mathrm{~kg}$ kotoran sapi, dan ditambahkan $100 \mathrm{~g}$ tepung tulang, $100 \mathrm{~g}$ tepung kerang, dan $100 \mathrm{~g}$ gula merah. Semua bahan dimasukkan ke dalam stoples plastik dan difermentasi selama 6 minggu.

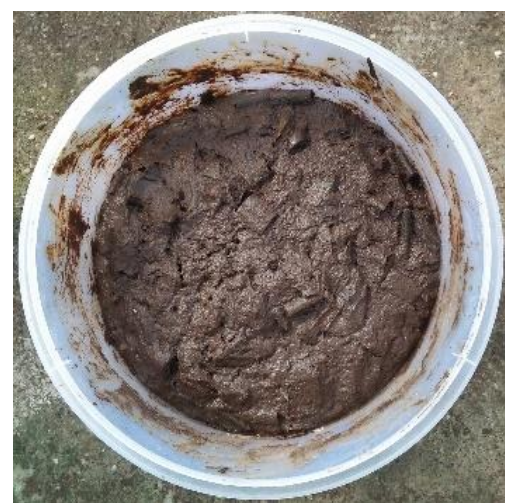

(a)

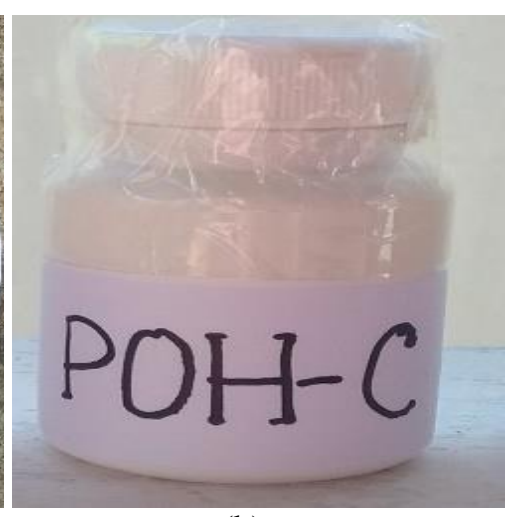

(b)

Gambar 3. (a) POH padat, dan (b) POH cair

Demonstrasi plot penggunaan pupuk hayati pada tanaman jagung di lapangan

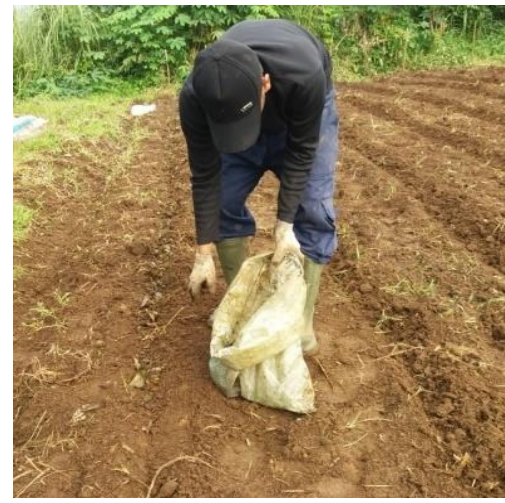

(a)

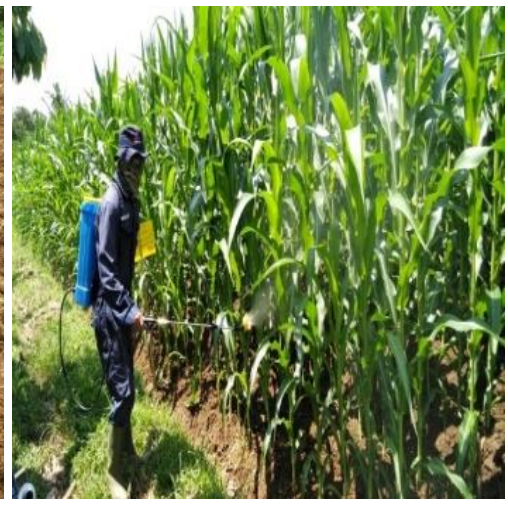

(b)

Gambar 4. (a) Pemberian POC padat sebelum tanam, dan (b) Penyemprotan POH cair pada 50 hst 


\section{HASIL DAN KETERCAPAIAN SASARAN}

Hasil pelatihan pembuatan pupuk hayati yang dilakukan secara in house, kelompok tani yang dundang dua kelompok, mahasiswa dan alumni satu kelompok, dengan total peserta 30 orang. Peserta sangat antusias mengikuti kegiatan pelatihan, hal ini dilihat dari kehadiran peserta mulai awal sampai selesainya kegiatan.

Pembuatan $\mathrm{POH}$ yang berasal dari bahan organik di sekitar lokasi, seperti eceng gondok, kotoran sapi, sumber kalsium dan konsorsium bakteri dari hasil penelitian sebagai dekomposer cukup berhasil. POH dihasilkan dari program ini berbentuk padat dan cair, yang masing-masingnya mempunyai keuntungan tersendiri. POH padat lebih banyak memperbaiki sifat fisik dan biologi tanah, sedangkan pemberian pupuk organik yang berbentuk cair membantu distribusi hara lebih merata, tidak akan terjadi penumpukan konsentrasi pupuk di satu tempat, karena pupuk ini $100 \%$ larut dan merata. Pupuk cair yang disemprotkan langsung ke permukaan daun secara cepat mengatasi defesiensi hara dan mampu menyediakan hara. Inokulan mikroba pada pupuk organik dapat menghasilkan metabolit yang membantu dekomposisi limbah organik dan meningkatkan kualitas humus (Barker and Bryson, 2006).

Penanaman jagung hibrida varietas Pioneer 32 dilakukan pada 2 periode tanam dari bulan September 2018 sampai Juni 2019. Jagung dipanen pada umur 115 hari dengan rata-rata hasil 8,6-11,2 t/ha. Variabel pertumbuhan vegetatif dan generatif tanaman jagung disajikan pada Tabel 1 dan 2 berikut.

Tabel 1. Pertumbuhan vegetatif tanaman jagung lahan yang diberi perlakuan tanpa $\mathrm{POH}, \mathrm{POH}$ pada dan $\mathrm{POH}$ padat+cair

\begin{tabular}{lcccc}
\hline \multicolumn{1}{c}{ Perlakuan } & Tinggi tanaman $(\mathrm{cm})$ & Jumlah daun (helai) & Panjang daun $(\mathrm{cm})$ & Lebar daun $(\mathrm{cm})$ \\
\hline Tanpa POH & 264 & 16 & 101,5 & 9,7 \\
POH padat & 276 & 17 & 102,1 & 9,8 \\
POH padat + cair & 295 & 17 & 103,2 & 10,2 \\
\hline
\end{tabular}

Pemberian $\mathrm{POH}$ dalam bentuk padat atau cair meningkatkan pertumbuhan tinggi tanaman, jumlah daun, panjang dan lebar daun jagung dibanding tanpa POH (Urea, SP-36, KCL). Peningkatan pertumbuhan disebabkan sumbangan hara dari pupuk hayati cair. Martinez-Alcantara, Martines-Cuenca, Bermejo, Legaz, and Quinones (2016) menyatakan penggunaan pupuk cair hewan dan nabati dapat meningkatkan biomassa tanaman, kandungan karbohidrat daun, serapan hara makro dan mikro tanaman dibandingkan tanpa pupuk cair.

$\mathrm{POH}$ mengandung mikroba yang menguntungkan bagi tanah dan tanaman. Mikroba membantu mengikat $\mathrm{N}$ dari udara dan melarutkan $\mathrm{P}$ yang terikat pada koloid tanah. Mikroba tertentu mensekresi IAA yang berfungsi sebagai perangsang pertumbuhan tanaman. Dua genera bakteri (Bacillus dan Pseudomonas) yang diinokulasikan ke dalam POH termasuk bakteri yang dapat merangsang pertumbuhan tanaman (Sondang Anty, Siregar dan Hayatunufus, 2018). Bakteri genera ini merupakan bakteri yang mempunyai kemampuan menghasilkan fitohormon, khususnya IAA dalam jumlah besar (Khakipour, Khavazi, Mojolali. Mojallali, Pazira and Asadirah (2008). Hal ini diperkuat dengan hasil penelitian Wong, Tan, Ge, Chen and Yong (2015) bahwa pupuk hayati sangat berperan pada masa pertumbuhan vegetatif tanaman.

Aleem, Isar and Malik (2003) menyatakan mekanisme dan cara kerja komunitas mikroba dalam pupuk organik hayati adalah meningkatkan hara dan zat perangsang tumbuh serta mengurangi aktivitas patogen tanaman. Pusat Penelitian Bioteknologi LIPI (2015) melaporkan bahwa penggunaan pupuk organik cair dapat mengurangi penggunaan pupuk kimia sebesar 30-50\% dan meningkatkan produksi.

Peran mikroba dalam siklus unsur hara penting karena ketersediaan unsur hara berkaitan erat dengan aktivitas mikroba yang terlibat (Pelczar and Chan, 2005). Mekanisme peran mikroba terhadap tanaman adalah (1) Meningkatkan ketersediaan nutrisi bagi tanaman (biofertilizer), (2) memproduksi fitohormon (biostimulant), (3) Menghambat produksi etilen, dan (4) Menekan perkembangan hama dan penyakit (bioprotectant) (Bloemberg and Lugtenberg, 2001). 
Tabel 2. Pertumbuhan vegetatif tanaman jagung lahan yang diberi perlakuan tanpa $\mathrm{POH}, \mathrm{POH}$ padat dan $\mathrm{POH}$ padat+cair

\begin{tabular}{lccccc}
\hline Perlakuan & $\begin{array}{c}\text { Jumlah } \\
\text { baris/tongkol } \\
\text { (baris) }\end{array}$ & $\begin{array}{c}\text { Jumlah } \\
\text { biji/baris (biji) }\end{array}$ & $\begin{array}{c}\text { Bobot } \\
\text { biji/tongkol (g) }\end{array}$ & $\begin{array}{c}\text { Bobot } \\
100 \text { biji (g) }\end{array}$ & $\begin{array}{c}\text { Hasil/hektar } \\
\text { (ton) }\end{array}$ \\
\hline Tanpa POH & 16 & 39 & 167,3 & 25,1 & 9.9 \\
POH padat & 16 & 40 & 178,0 & 25,5 & 10,7 \\
POH padat + cair & 18 & 41 & 196,6 & 38,5 & 11,8 \\
\hline
\end{tabular}

Tongkol jagung dengan perlakuan tanpa $\mathrm{POH}, \mathrm{POH}$ padat dan $\mathrm{POH}$ padat + cair dapat dilihat pada Gambar 7 berikut.

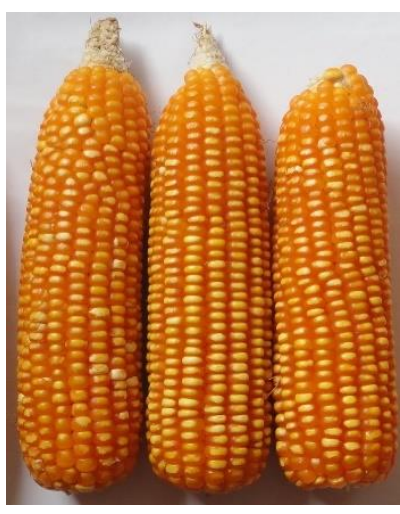

(a)

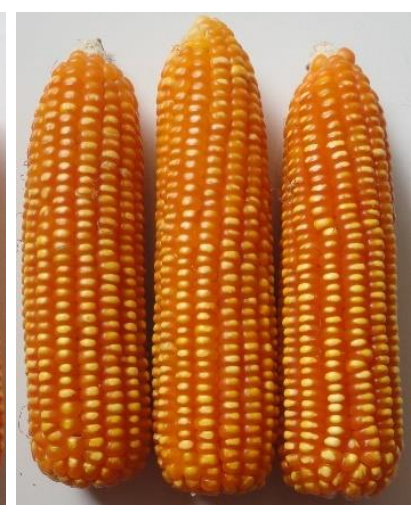

(b)

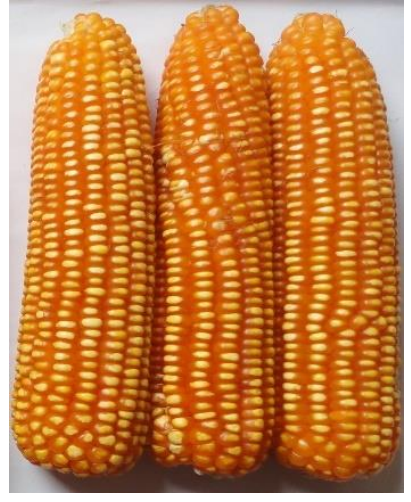

(c)

Gambar 5. (a) Jagung tanpa POH, (b) Jagung POH padat, (c) Jagung POH padat + cair

Komponen hasil dan produksi jagung yang diberikan $\mathrm{POH}$ memberikan hasil yang lebih baik daripada tanpa $\mathrm{POH}$. Komponen hasil akan menggambarkan hasil yang akan diperoleh. Sumbangan hara dari POH akan meningkatkan pengisian biji jagung, terutama $\mathrm{P}$ dan $\mathrm{K}$. Produksi jagung dengan menggunakan $\mathrm{POH}$ padat+cair meningkat sebesar 19\% dibandingkan dengan tanpa $\mathrm{POH}$, sedangkan $\mathrm{POH}$ padat meningkat sebesar $8 \%$ dibandingkan dengan tanpa $\mathrm{POH}$. Peningkatan kandungan bahan organik tanah dan mikroba yang terkandung dalam pupuk hayati meningkatkan ketersediaan hara bagi tanaman jagung. Penggunaan pupuk hayati dengan memanfaatkan kearifan lokal dari bahan utama eceng gondok yang difermentasikan dengan bioaktivator yang diisolasi dari rizosfer dan endofit tanaman menyumbang hara bagi tanaman.

Pemberian kompos dapat memperbaiki kesuburan tanah, terutama sifat fisik dan biologi tanah. Pemberian pupuk cair meningkatkan serapan hara oleh daun tanaman. Pupuk organik mempunyai beberapa kelebihan, yaitu selain proses pelepasan hara secara bertahap, pupuk organik juga dapat memperbaiki kesuburan tanah (Martajaya, Agustina dan Syekhfani, 2010). Harapan petani Indonesia adalah tanah subur dan sehat, produksi pangan meningkat dengan produk pangan yang sehat dalam rangka mendukung ketahanan pangan nasional. Tabel 3 menunjukkan hasil evaluasi pada sebelum dan sesudah pelaksanaan pengabdian.

Tabel 3. Parameter yang dievaluasi dalam pelaksanaan pengabdian

\begin{tabular}{lcc}
\hline \multicolumn{1}{c}{ Parameter } & Sebelum Pengabdian & Setelah Pengabdian \\
\hline $\begin{array}{l}\text { Pengetahuan dan keterampilan peserta tentang pupuk } \\
\text { hayati }\end{array}$ & $30 \%$ & $60 \%$ \\
Peserta yang membuat pupuk hayati & $22 \%$ & $50 \%$ \\
Peserta yang menggunakan pupuk hayati & $30 \%$ & $60 \%$ \\
Peserta yang mengetahui teknik budidaya jagung & $50 \%$ & $70 \%$ \\
\hline
\end{tabular}


Tabel 3 menunjukkan peningkatan yang cukup baik dari seluruh parameter yang dievaluasi. Secara perlahan petani akan merubah sikap terhadap inovasi setelah melihat langsung hasil dari penerapan pupuk hayati di lapangan. Peningkatan produksi jagung, peningkatan pengetahuan dan keterampilan dalam membuat dan menggunakan pupuk hayati tidak terhenti sampai kebutuhan pribadi saja, sebaiknya perlu keberlanjutan dalam hal:

a. Tersedianya pupuk hayati yang aman bagi pertanian dan masyarakat.

b. Terpenuhinya permintaan pasar akan pupuk hayati

c. Meningkatkan pendapatan masyarakat (kelompok tani dan alumni) dalam produksi maupun pemasaran pupuk hayati.

Keberhasilan teknologi ini akan memperbaiki kesuburan tanah yang berdampak kepada peningkatan produksi jagung di Kabupaten Limapuluh Kota sampai 19\%. Pengetahuan dan keterampilan masyarakat yang mampu membuat dan menggunakan pupuk hayati pada budidaya tanaman, khususnya tanaman jagung dengan teknik budidaya yang benar mengalami peningkatan 20-30\%.

\section{KESIMPULAN}

Penerapan pupuk hayati meningkatkan pertumbuhan vegetatif dan generatif tanaman jagung. Produksi jagung pada lahan demplot yang diberi pupuk hayati padat+cair meningkat sebesar 19\% dibandingkan lahan tanpa $\mathrm{POH}$. Evaluasi terhadap program menunjukkan peningkatan pengetahuan dan keterampilan masyarakat, peningkatan dalam membuat dan menggunakan pupuk hayati pada tanaman jagung dengan teknik budidaya yang benar. Keuntungan lain dari program ini adalah membuka peluang bagi masyarakat untuk menjadi produsen pupuk hayati.

\section{UCAPAN TERIMA KASIH}

Penulis mengucapkan terima kasih kepada Direktorat Riset dan Pengabdian Masyarakat Kemenristek Dikti yang telah mendanai Program ini. Semoga program ini berkelanjutan dan hasilnya bermanfaat bagi masyarakat umum.

\section{DAFTAR PUSTAKA}

Aleem, A., J. Isar, and A. Malik. 2003. Impact of Long-Term Application of Industrial Wastewater on the Emergence of Resistance Traits in Azotobacter chroococcum Isolated from Rhizospheric Soil. Bioresour Technol 86(1): 713.

Balai Penelitian Tanah. 2005. Prospek Pengembangan dan Pemanfaatan Pupuk Organik di Indonesia. Balai Penelitian Tanah, Bogor.

Barker, A.V. and G.M. Bryson. 2006. Comparisons of Composts with Low or High Nutrient Status for Growth of Plants in Containers. Commun. Soil Sci. Plant. 37: 1303-1319.

Bloemberg, G.V. and B.J.J. Lugtenberg. 2001. Moleculer Basis of Plant Growth Promotion and Biocontrole by Rhizobacteria. Plant Biology 4: 343-350.

Khakipour, N.K., H. Khavazi, E. Mojallali, Pazira, Asadirahmani, 2008. Production of Auxin Hormone by Fluorescent Pseudomonads. American-Eurasian. J. Agric \& Environ Sci 4(6): 678-692.

Malusa E. and N. Vassilev. 2014. A Contribution to Set a Legal Framework for Biofertilizers. Appl. Microbiol Biotechnol 98: 6599-6607.

Martajaya, M., L. Agustina, dan Syekhfani. 2010. Metode Budidaya Organik Tanaman Jagung Manis di Tlogomas Malang. Jurnal Pembangunan dan Alam Lestari 1(1): 1-8.

Martinez-Alcantara, B., M.R. Martinez-Cuenca, A, Barmejo, F. Legaz, and A. Quinones. 2016. Liquid Organic Fertilizers for Sustainable Agriculture: Nutrient Uptake of Organic versus Mineral Fertilizer in Citrus Trees. PLoS One 11(10): e0161619. https://doi.org/10.1371/journal.pone0161619

Nuryati, L., B. Waryanto, Noviati, dan R. Widaningsih. 2015. Outlook Komoditas Tanaman Pangan : Jagung. Pusat Data dan Sistem Informasi Pertanian. Kementerian Pertanian. ISSN: 1907 - 1507. 82 hal.

Pelczar, M.J. and E.C.S., Chan. 2005. Element of microbiology. Alih bahasa: Hadioetomo $d k k$. UI Press, Jakarta.

Pringadi, K. 2009. Peran Bahan Organik dalam Peningkatan Produksi Padi Berkelanjutan Mendukung Ketahanan Pangan Nasional. Balai Besar Penelitian Tanaman Padi. Pengembangan Inovasi Pertanian 2(1): 48-64. 
Pusat Penelitian Bioteknologi LIPI. 2015. Pupuk Organik. Lembaga Ilmu Pengetahuan Indonesia, Bogor.

Rusastra, W., Saptana, A. Djulin. 2005. Roadmap Pengembangan Pupuk Organik dalam Mendukung Pembangunan Pertanian. Departemen Pertanian. Buku VI:167-211.

Schaad, N.W., J.B. Jones, W. Chun. 2001. Plant Pathogenic Bacteria. APS Press, St. Paul, Minnesota.

Sondang, Y. dan K. Anty. 2017. Penggunaan Kompos sebagai Substitusi Pupuk Anorganik dalam Upaya Meningkatkan Produksi Jagung. Prosiding Seminar Nasional: Inovasi Teknologi dalam Mewujudkan Kemandirian Pangan Nasional Berkelanjutan, Politeknik Pertanian Negeri Payakumbuh 4 Oktober 2017. ISBN 978-602-51262-0-8, hal $37-42$.

Sondang, Y., K. Anty, dan R. Siregar. 2018. Application of Corn Endofit Bacteria (Pseudomonas sp and Bacillus sp) to The Physiological Quality of corn seed. Proseding Seminar Nasional: Peranan Teknologi Perbenihan Berbasis Sumberdaya Lokal dalam Mendukung Ketahanan Pangan, 26 September 2018, ISBN: 978-602-51262-2-2, hal 101-108.

Sondang, Y., R. Alfina, dan K. Anty. 2015. Karakteristik Mikroorganisme Lokal (MOL) dari Berbagai Sumber Bahan Organik. Prosiding Seminar Nasional: Ketahanan Pangan dan Pertanian Berkelanjutan, Tantangan dan Peluang Implementasi Teknologi dalam Perspektif Nasional, Politeknik Pertanian Negeri Payakumbuh 07 Oktober 2015. Buku 2. ISBN: 978-979-98691-7-3, hal 104-109.

Sulaiman A.A., I.K. Kariyasa, Hoerudin, M. FoodSt, K. Subagyono, Suwandi, dan F.A. Bahar, 2017. Cara Cepat Swasembada Jagung. Sekretariat Jenderal Kementerian Pertanian RI. ISBN: 978979 15689 99. 101 hal.

Wong WS., S.N. Tan, L. Ge, X. Chen, and J.W.H. Yong. 2015. The Importance of Phytohormones and Microbes in Biofertilizer in book Microbial Phytohormones a Key Role in Mitigating The Salt Induced Damaged in Plant, pp 105-158. Maheshwari Dinesh K. https://doi.org/10.1007/978-3-319-24654-3_6 